\title{
A simple and effective technique to guide the ectopic eruption of a first permanent molar: a case report
}

\author{
Uma técnica simples e eficaz para guiar a erupção ectópica de um \\ primeiro molar permanente inferior: um relato de caso
}

\author{
Kelly Maria Silva Moreira* \\ Micaela Cardoso ${ }^{* *}$ \\ Cassiano Salvaterra*** \\ Regina Maria Puppin Rontani ${ }^{* * * *}$ \\ João Sarmento Pereira Neto ${ }^{* * * *}$
}

\begin{abstract}
Objective: To report the case of a 5-year-old patient diagnosed with ectopic eruption of the lower left first permanent molar that was mesially inclined, initially based on the clinical examination and followed by periapical radiographic examination. Case report: The treatment consisted of the placement and maintenance of an elastic separator for one week between the space of the lower second primary molar and the lower first permanent molar. Subsequently, the elastic separator was removed, allowing the tooth to erupt freely. After 1 week without the elastic separator, the patient returned and the tooth was observed in adequate eruption. Final considerations: The treatment of ectopic eruption was effective, since it repositioned the first permanent molar and allowed its vertical eruption in a short time using a simple technique. Moreover, the early diagnosis of this eruption disorder of permanent molar in mixed dentition is important to avoid more complex treatments and enable normal occlusion development.
\end{abstract}

Keywords: Mixed dentition. Pediatric dendistry. Tooth eruption.

\section{Introduction}

Researchers have reported the prevalence of malocclusions in approximately 26\% to $39 \%$ of children, which can require treatment depending on the age range investigated ${ }^{1}$. Premature loss and prolonged retention of primary teeth are important causes of malocclusion ${ }^{2}$.

Ectopic eruption is defined as the eruption of a tooth in an atypical position or orientation ${ }^{3}$. It often occurs in the developing mixed dentition, characterized by molar eruption under the distal undercut of the second molar, and consequently failures to erupt in the normal occlusal plane because of the presence of a barrier ${ }^{4-6}$. The etiology of the ectopic eruption of the first permanent molar is not completely understood ${ }^{3,6}$. It may be considered to be multifactorial ${ }^{3}$ and primarily dependent on the tooth germ position ${ }^{5}$. Most causes are abnormally large first permanent and second primary molars combined with inadequate arch size, and a mesially inclined eruption, among other factors as described by some authors ${ }^{2,3,6,7}$.

Specialist in Pediatric Dentistry and Family Health Strategy, MS program in the Department of Pediatric Dentistry, Piracicaba Dental School, State University of Campinas, Piracicaba, São Paulo, Brazil.

MS, Phd program in Department of Pediatric Dentistry, Piracicaba Dental School, State University of Campinas, Piracicaba, São Paulo, Brazil.

DDS student in the Piracicaba Dental School, State University of Campinas, Piracicaba, São Paulo, Brazil.

PhD, Department of Pediatric Dentistry, Piracicaba Dental School, State University of Campinas, Piracicaba, São Paulo, Brazil. 
Ectopic eruption affects both genders equaly ${ }^{3}$. It is more frequent in the maxillary $\operatorname{arch}^{8}$ and the most affected teeth are maxillary first permanent molars and canines, followed by the mandibular canine, mandibular second premolar, and maxillary lateral incisors ${ }^{4}$. Thus, impaction mostly occurs in the maxillary first molar during mixed dentition ${ }^{2,6}$. Generally, first molars are affected in approximately $2-6 \%$ of the population ${ }^{3,6,8}$.

Diagnosis is performed both radiographically (periapical, bitewing, or orthopantomograph) and clinically $^{2-4}$. Ectopic eruption may be classified as reversible (permanent molar is spontaneously self-corrected and erupts in the normal position) or irreversible (permanent molar remains blocked by the primary molar) ${ }^{3,7}$. Therefore, to provide a correct diagnosis, it is important to identify the condition in order to understand the analyses of mixed dentition and the development of primary and secondary dentitions, as well as to recognize a normal occlusion ${ }^{2}$.

An interceptive orthodontic treatment potentially reduces the need for a more complex orthodontic treatment; thus, it may be of particular benefit to patients and clinicians in areas of limited access to specialist orthodontic services ${ }^{1}$. Among them, we may highlight traction to distalize maxillary first permanent molars using elastics ${ }^{5,7}$, interproximal wedges $^{6}$, and eventually segmented springs, transplantation ${ }^{5}$ or removable/fixed appliances, such as Pendulum, Distal Jet, Jones jig, NiTi coils, and headgear ${ }^{8}$. Individualized treatment plans must be established according to the need of each patient ${ }^{5}$.

Since the closest contact between the first molar and the primary second molar causes an atypical resorption located in the distal surface of the primary molar and subsequent locking of the permanent molar within the resorption cavity ${ }^{7}$, this study aimed to report a clinical case on the development of a mandibular left first permanent molar with ectopic eruption.

\section{Case report}

A 5-year-old male patient was referred to the pediatric dentistry clinic of the Piracicaba Dental School - FOP/UNICAMP, SP, Brazil. In anamnesis, the guardian reported that the child had no systemic changes. In addition, at extraoral examination of the child presented no alterations. During intraoral clinical examination, we observed complete and normal development of the mixed dentition, but the mandibular left first permanent molar was partly visible and mesially inclined (Figure 1A). There was no complaint of pain or discomfort. All teeth were free of caries or restorations and aligned normally. Periapical radiograph confirmed our clinical analysis, and the left first permanent molar was under the distal undercut of the primary second molar (Figure 1B). Thus, the treatment plan was focused on that tooth.
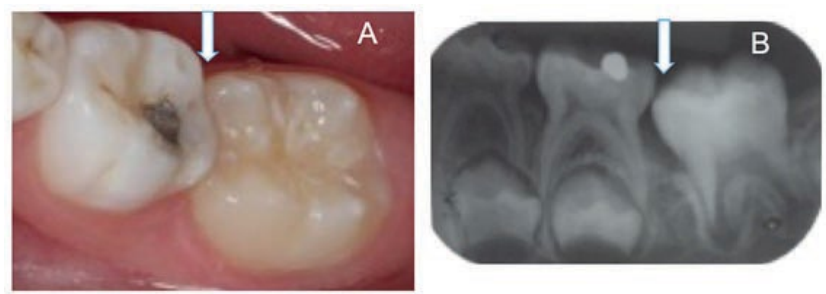

Figure 1 - A) Clinical view of the impacted permanent molar and B) Periapical radiograph of the impacted permanent molar - white arrows show the mandibular left first permanent molar impacted on the distal surface of the second left primary molar

Source: authors' elaboration.

In the first appointment, an elastic separator 5/32" (Morelli, Sorocaba, Brazil) was placed using dental floss (Johnson \& Johnson, São Paulo, São Paulo, Brazil) and kept for one week between the interproximal space of the primary mandibular second molar and the mandibular first permanent molar. The elastic separator worked by distally pushing the molar (Figure 2).
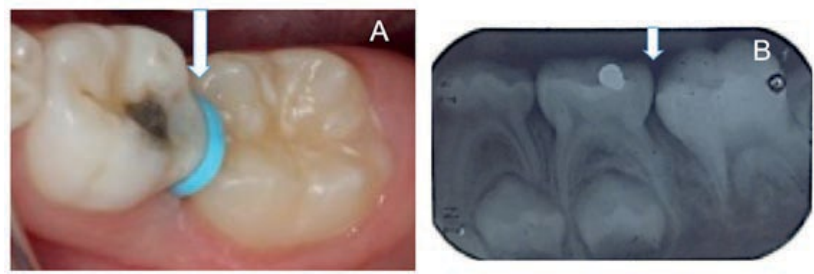

Figure 2 - In the first appointment, after inserting the elastic separator: A) Elastic separator in position between the second primary molar and first permanent molar, B) Periapical radiograph of the impacted permanent molar - white arrows show the mandibular left first permanent molar impacted on the distal surface of the second left primary molar

Source: authors' elaboration.

In the second appointment, distal movement of the mandibular right first permanent molar was observed clinically and radiographically. The elastic was removed using blunt-tipped probe, allowing the free tooth to erupt (Figure 3). After 1 week, the patient returned and the tooth was observed in adequate eruption. Figure 4 shows the 2-month follow-up.
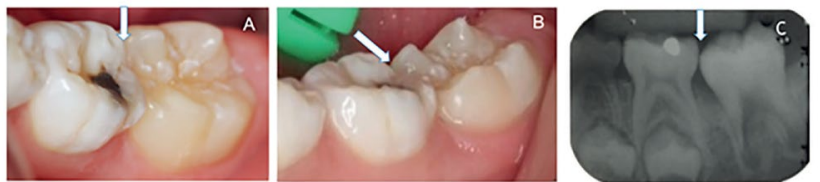

Figure 3 - In the second appointment, after removal of the elastic separator: Occlusal A) and lateral B) view of the permanent mandibular first molar in unchanged eruption, C) Periapical radiograph of the impacted permanent molar - white arrows show the mandibular left first permanent molar impacted on the distal surface of the second left primary molar

Source: authors' elaboration. 

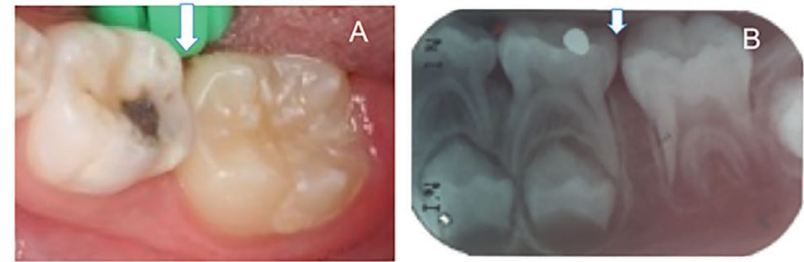

Figure 4 - Two-month follow-up: Occlusal A) view of the permanent mandibular first molar in occlusal position, B) Periapical radiograph of the impacted permanent molar - white arrows show the well-positioned mandibular left first permanent molar

Source: authors' elaboration.

\section{Discussion}

Eruption disorders of first permanent molars are characterized by additional symptoms of abnormality in three-quarters of those affected. They are statistically significant more frequently in conjunction with crowding, lateral crossbite, tendency for Class III malocclusion, and individual deviations of teeth 9 . In this case report, the patient was five years old and presented maxillary atresia and crowding in the lower arch. From a therapeutic point of view of the craniofacial growth, the authors relate that an eruption disorder in the first permanent molar area is an early indication of a dentition at high risk of defective development, eventually leading to a lack of space in the sagittal and transverse dimensions.

Several different methods have been proposed to treat ectopic eruption of the first permanent molar to avoid premature loss of the second primary molar. Moyers $^{10}$ (1991) has proposed the manual abrasion of the second primary molar to facilitate the eruption of the first permanent molar. Other researchers ${ }^{11}$ have reported using twisted brass wire at the distal surface of the second primary molar and at the mesial surface of the first molar. This technique may have some variations, but it provides pressure at the contact point, forcing the distal movement of the permanent molar and the mesial movement of the primary molar. Moreover, a study used the modified Halterman method to distalize the first permanent molar. This technique includes the use of a bilateral extension in the distal surface with a band cemented on the second primary molar, thus allowing distal movement of the first permanent molar ${ }^{12}$. Although the authors obtained clinical success, it is a more elaborate device with cost disadvantages, and it is a more complex technique compared to the use of orthodontic elastic separators.

Thus, the ectopic eruption of the permanent molar, if not diagnosed and treated early, may mask other occlusion and malocclusion disorders and uncontrolled craniofacial growth, and the permanent molar may suffer ankylosis and cause pericementitis, lymphadenitis, or follicular cyst $^{2}$. Therefore, the clinical and radiographic examination (ideally during the early mixed dentition period $)^{5}$, in order to allow adequate diagnostic and treatment, are key factors in the prevention of these complications.

However, the use of elastic separators seems to be a well-accepted and less invasive technique, since placing the elastic separator in the permanent molar and using it as a guide creates space for the eruption without interference, as presented ${ }^{13}$. In addition, disimpaction with orthodontic separators to correct the ectopic eruption of maxillary first permanent molars was successful, resulting in normal vertical eruption and arch length preservation $^{7}$, as in this case report.

This case reportshowed a successful disimpaction of first permanent molar in an easy and quick way and with no discomfort for the patient. Further studies are necessary to assess the effectiveness of this technique using orthodontic separators for ectopic eruption treatment in different degrees.

\section{Conclusion}

The treatment of ectopic eruption was effective, since it repositioned the first molar and allowed its vertical eruption in a short time using a simple technique.

\section{Acknowledgments}

The authors are thankful to the Writing Area/General Coordination of the University of Campinas - Unicamp, SP, Brazil. Additionally, the authors thank Kelly Guedes de Oliveira Scudine for her support on the captions of images used in this manuscript.

\section{Resumo}

Objetivo: relatar o caso de um paciente de 5 anos de idade diagnosticado com erupção ectópica do primeiro molar permanente inferior esquerdo, que estava mesialmente inclinado, inicialmente, com base em exame clínico, seguido de exame radiográfico periapical. Relato de caso: o tratamento consistiu na colocação e manutenção de um elástico separador, por uma semana, entre o espaço do segundo molar decíduo inferior e o primeiro molar permanente inferior. Posteriormente, o elástico separador foi removido, permitindo que o dente estivesse livre para entrar em erupção. Após uma semana sem o elástico separador, o paciente retornou e foi observado o dente em erupção adequada. Considerações finais: o tratamento da erupção ectópica foi efetivo, uma vez que reposicionou o primeiro molar permanente e possibilitou sua erupção vertical em curto tempo, utilizando uma técnica simples. Além disso, o diagnóstico precoce dessa desordem de erupção de molar permanente na dentição mista é importante para evitar tratamentos mais complexos e possibilitar o desenvolvimento da oclusão normal.

Palavras-chave: Dentição mista. Odontopediatria. Erupção dental. 


\section{References}

1. Borrie F, Bearn D. Interceptive orthodontics--current evidence-based best practice. Dent Update 2013; 40(6):442-4.

2. Cossman MH. Ectopic eruption: first molar impaction in the mixed dentition. Dent Dig 1970; 76(8):349-53.

3. Hennessy J, Al-Awadhi EA, Dwyer LO, Leith R. Treatment of ectopic first permanent molar teeth. Dent Update 2012; 39(9):656-8.

4. Rajesh R, Naveen V, Amit S, Baroudi K, Sampath Reddy C, Namineni S. Treament of ectopic mandibular second permanent molar with elastic separators. Case Rep Dent 2014; 2014:621568. DOI: 10.1155/2014/621568. Epub 2014.

5. Valmaseda-Castellón E, De-la-Rosa-Gay C, Gay-Escoda C. Eruption disturbances of the first and second permanent molars: results of treatment in 43 cases. Am J Orthod Dentofacial Orthop 1999; 116(6):651-8.

6. Kupietzky A. Correction of ectopic eruption of permanent molars utilizing the brass wire technique. Pediatr Dent 2000; 22(5):408-12.

7. Seehra J, Winchester L, DiBiase AT, Cobourne MT. Orthodontic management of ectopic maxillary first permanent molars: a case report. Aust Orthod J 2011; 27(1):57-62.

8. Kennedy DB. Management of an ectopically erupting permanent mandibular molar: a case report. Pediatr Dent 2008; 30(1):63-5.

9. Salbach A, Schremmer B, Grabowski R, Stahl de Castrillon F. Correlation between the frequency of eruption disorders for first permanent molars and the occurrence of malocclusions in early mixed dentition. J Orofac Orthop 2012; 73(4):298-306.

10. Moyers RE. Ortodontia. 4. ed. Rio de Janeiro: Guanabara Koogan; 1991.

11. Almeida RR, Almeida-Pedrin RR, Almeida MR, Ferreira FPC, Almeida PCMR. Recuperadores de espaço e sua aplicação clínica. Guidelines on the use of space regain. Revista da FOL/Unimep 2002; 14(2):15-20.

12. Eto LF, Correa PH, Da Silva DM. Effectiveness on correction of the ectopic eruption of the first permanent molars. Ortho Sci 2011; 4(16):806-11.

13. Ferreira MC, Oliveira RC, Campos V. Ectopia do primeiro molar permanente superior: Relato de um caso clínico. Odontoped \& Odontol do Bebê 2001; 4(20):279-344.

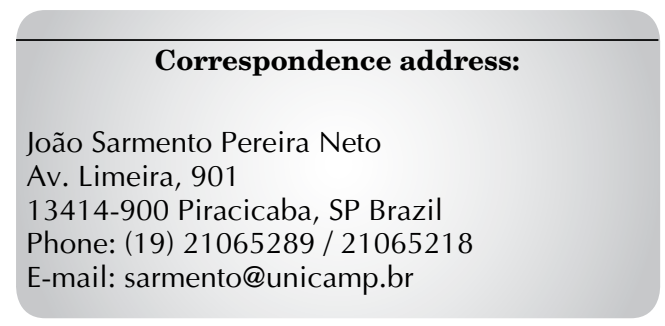

Recebido: 01/01/2016. Aceito: 22/09/2016. 